\title{
Use of the euryhaline bivalve Potamocorbula amurensis as a biosentinel species to assess trace metal contamination in San Francisco Bay
}

\author{
Cynthia L. Brown*, Samuel N. Luoma \\ U.S. Geological Survey, Mail Stop 465, 345 Middlefield Road, Menlo Park, California 94025, USA
}

\begin{abstract}
Potamocorbula amurensis was assessed as a biosentinel species in San Francisco Bay, California, USA. Uptake of metal in both the laboratory and field showed that $P$. amurensis was sufficiently responsive to $\mathrm{Ag}, \mathrm{Cd}, \mathrm{Cr}, \mathrm{Ni}$ and $\mathrm{V}$ to detect environmental differences in exposure. It was less suitable as an indicator of $\mathrm{Cu}$ and $\mathrm{Zn}$ contamination. Concentration factors for $P$. amurensis were: $\mathrm{Ag}, 386000$; $\mathrm{Cd}, 50200 ; \mathrm{Cr}, 36600 ; \mathrm{Cu}, 12200 ; \mathrm{Ni}, 5200$; and $\mathrm{Zn}, 115500$. Samples were collected from 6 stations throughout the bay at near-monthly intervals from January 1991 to March 1992. Variability within a collection was influenced by gut content and animal size. Other sources of variability were time (coefficient of variation $(\mathrm{CV})=10$ to $21 \%$ ], small-scale spatial variability (within $3 \mathrm{~km}, \mathrm{CV}=10$ to $25 \%$ ), and large-scale spatial variability $(C V=3.3$ to $12.4 \%)$. Depuration for $48 \mathrm{~h}$ was necessary to mitigate bias from gut content. Precision was improved by analyzing large numbers of individuals (60 to 120) separated into several ( 5 to 14 ) composites at each collection and by determining, from regression, the mean and variance for samples with significant correlations between metal concentration and shell length. Repeated monthly sampling increased the accuracy of long-term site characterizations. Temporal variability was small because of drought. The grand means of the concentrations of $\mathrm{Ag}, \mathrm{Cd}, \mathrm{Cr}, \mathrm{Ni}$, and $\mathrm{V}$ in the tissues of $P$. amurensis at each station for the 15 mo period revealed persistent contamination from industrialized Suisun Bay to the mouth of San Francisco Bay. Demonstration of responsiveness, precision and accuracy should be a prerequisite for the optimal use of biosentinels.
\end{abstract}

KEY WORDS: Potamocorbula amurensis · Biosentinel - Trace metals - San Francisco Bay - Size · Gut content Variability

\section{INTRODUCTION}

Metal concentrations in the tissues of organisms (sentinel species) are widely used to evaluate the fate and distribution of biologically available contamination in marine and estuarine ecosystems (Bryan 1976. Phillips 1976, Bryan \& Hummerstone 1978, Bryan \& Uysal 1978, Goldberg et al. 1983). The characteristics of a suitable sentinel species are well described (Phillips 1977, Bryan et al. 1985, Campbell et al. 1989). If local or endemic species are employed as sentinels (the 'passive' biomonitoring approach; Borchardt et al. 1988), then the species should be abundant, distributed over the entire ecosystem of interest, large, and

\footnotetext{
•E-mail: clbrown@mailrcamnl.wr.usgs.gov
}

metal concentrations in their tissues should reflect environmental exposures. The effects on metal concentrations of biological factors (undigested gut content, individual variability, size, sex, reproductive stage, seasonal growth cycles) and environmental factors (salinity, river flow rate, contaminant discharge) must also be considered (Phillips 1977, Simkiss \& Taylor 1981, Bryan et al. 1985, Borchardt et al. 1988). The forthcoming series of papers will use a euryhaline biosentinel, the bivalve Potamocorbula amurensis, to assess the influence of physical (riverine influence, circulation patterns) and chemical (salinity) processes on metal contamination in San Francisco Bay, California, USA. The present paper approaches the question of whether biosentinels in general, and $P$. amurensis specifically, are suitable for use in such contaminant assessments 
The wide range of salinities that characterizes estuaries is a critical confounding factor in system-wide comparisons of biosentinel data. Salinity limits the range of habitats of potential sentinel species (Simkiss et al. 1982). Thus studies employing biosentinels in estuaries typically use different species for different salinity zones (Harris et al. 1979, Talbot \& Chegwidden 1982, Luoma \& Phillips 1988, Johns \& Luoma 1990). For example, the mussel Mytilus edulis is most commonly used as a marine sentinel species. 'Mussel watch' studies that include estuaries either limit their sampling to the salinity range of $M$. edulis or include a second species that is more tolerant to lower salinities (Goldberg et al. 1983). Increasing the number of species reduces the comparative power of the study. Potamocorbula amurensis lives throughout San Francisco Bay and has a unique ability to live in habitats with salinities ranging from 0.1 to $32 \%$.

Most bivalves bioaccumulate most metals proportionately to environmental exposures, at least as a first order approximation (Simkiss \& Taylor 1981). However, the metal accumulation 'strategy' (Rainbow 1993) can differ among species and among metals (South-

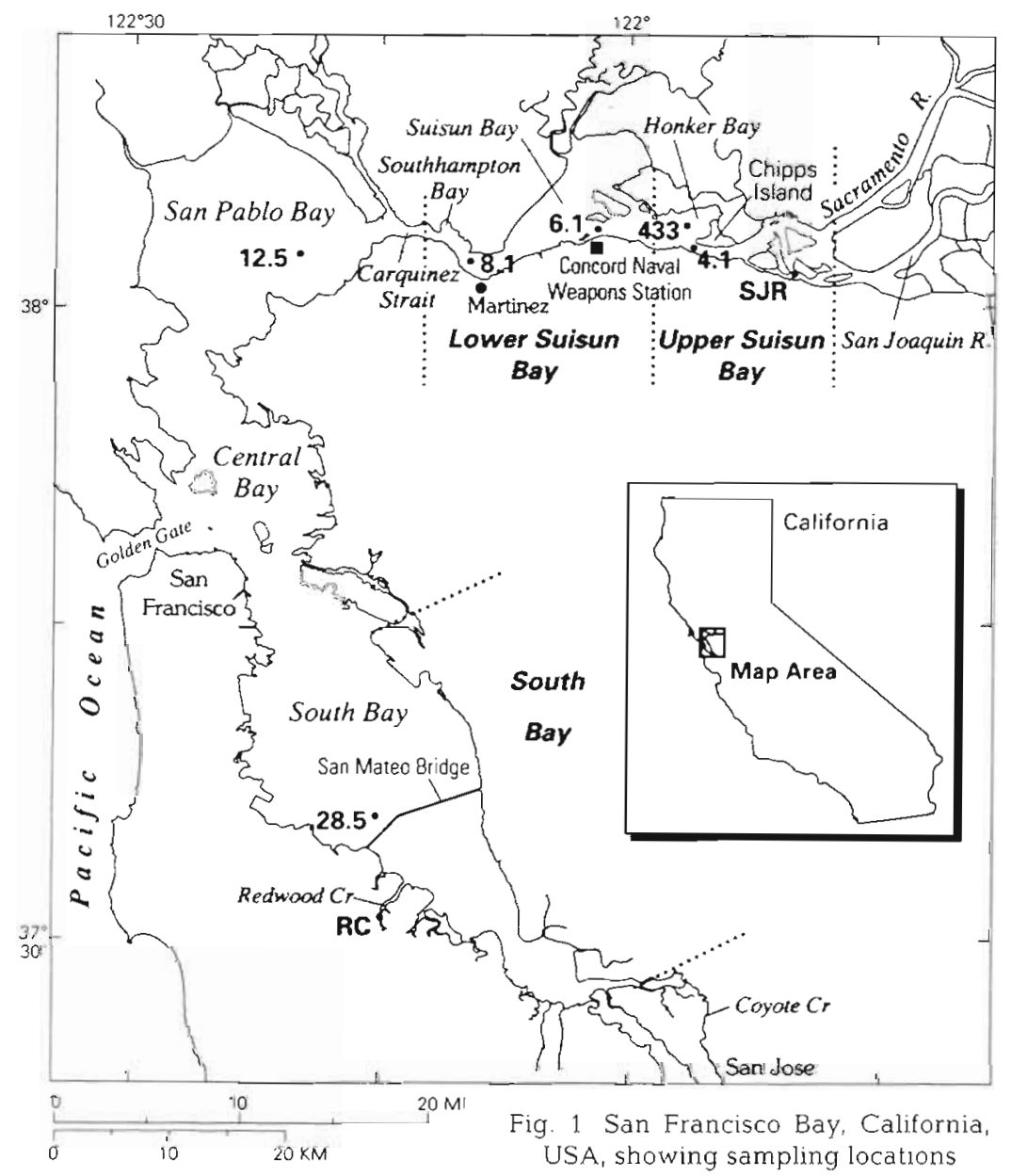

gate et al. 1983, Martincic et al. 1984). For example, field comparisons suggest that the mussel Mytilus edulis is not as responsive to $\mathrm{Cu}$ exposures as the oyster Ostrea edulis (Martincic et al. 1984) or a deposit feeding clam, Scrobicularia plana (Bryan \& Hummerstone 1978, Southgate et al. 1983). Some species may regulate $\mathrm{Zn}$, at least at low exposure concentrations, while metals such as $\mathrm{Pb}$ and $\mathrm{Cd}$ may be accumulated with direct proportionality to exposure concentrations (Phillips \& Rainbow 1989, Rainbow \& White 1989. Rainbow 1993). It is important to evaluate such strategies in biosentinel species. Here, responsiveness to metal exposure is determined in Potamocorbula amurensis by the study of dissolved metal uptake under controlled conditions (an approach used by Fischer 1988, 1989, Rainbow et al. 1990). Uptake is compared to that in another biosentinel, Macoma balthica (Luoma et al. 1985, Luoma \& Phillips 1988). These experiments were not meant to simulate the complex exposures of $P$. amurensis in nature, but merely to determine the nature of uptake in a simple exposure to bioavailable metal. Responsiveness is also assessed in the field along a suspected contamination gradient and concentration factors are compared to those of other species.

An important criticism of biosentinel data is that it can be highly variable. Sources of variability include gut content (LaTouche \& Mix 1982, Lobel et al. 1991b), animal size (Strong \& Luoma 1981, Bryan et al. 1983, 1985, Lobel 1987, Borchardt et al. 1988, Lobel et al. 1989, 1991a, Luoma et al. 1990), temporal variability (Boyden \& Phillips 1981. Goldberg et al. 1983, Luoma et al. 1985. 1990, Cain \& Luoma 1990), small-scale spatial variability (Krumgalz et al. 1989), and large-scale spatial variability. All are considered here for Potamocorbula amurensis

\section{FIELD SITE}

San Francisco Bay is a large urbanized estuary, composed of the North Bay and South Bay segments (Fig. 1). In the North Bay, which includes Suisun Bay and San Pablo Bay, wide temporal changes in salinity can occur, associated with temporal changes in freshwater inflow (Conomos et al. 1985). Suisun Bay is one of the U.S. estuaries most vulnerable to pollution effects because of its physical characteristics and indus- 
trial/urban waste discharges (Beasely et al. 1988). Previous studies reported trace metal enrichment in Suisun Bay, relative to upstream riverine sites (Luoma et al. 1990). South Bay is a semi-enclosed embayment with limited local freshwater inputs, although salinities can be reduced during high river flows. Studies of metals in water, sediments and sentinel species have documented contamination in the South Bay (Luoma \& Phillips 1988, Flegal et al. 1991).

Potamocorbula amurensis is a filter-feeding bivalve that invaded San Francisco Bay from estuaries in eastern Asia. It was first discovered in Suisun Bay in October 1986 (Carlton et al. 1990, Nichols et al. 1990). It quickly became abundant and is now established throughout most of the bay. Successful populations are found over a salinity range of 0.1 to $32 \%$, in the intertidal and subtidal, and in environments of widely differing sediment type, from fine clay to coarse sand. It is found in segments of the bay with large differences in potential food sources (terrestrial versus marine organic matter) (Jassby et al. 1993). Thus direct comparisons of bioavailable metal contamination among diverse estuarine settings in the bay was possible for the first time using this species.

The data reported here are from January 1991 through March 1992, a period of drought in the watershed of San Francisco Bay. The location of the freshwater/seawater interface was unusually stable. Salinities remained stable throughout most of the year with small decreases during March and April (Table 1). Thus some of the temporal environmental influences that might typically confound the responses of a biosentinel species to contamination in an estuary were reduced.

Characterizations of metal concentrations in sentinel species in earlier studies frorn San Francisco Bay were limited by the occurrence of those species for their abilities to survive) in specific segments of the bay (Luoma \& Phillips 1988, Luoma et al. 1990, Flegal et al. 1991). In the present work, $P$. amurensis were collected from a wide range of conditions: from the most

Table 1. Mean bottom salinities in parts per thousand (SD in parentheses) for channel stations in San Francisco Bay showing stability during the period of study, with a seasonal decrease during March and April

\begin{tabular}{|c|c|c|c|}
\hline \multirow[t]{2}{*}{ Location } & \multirow[t]{2}{*}{ Stn } & \multicolumn{2}{|c|}{ Mean } \\
\hline & & $\begin{array}{c}\text { Excluding } \\
\text { March and April }\end{array}$ & $\begin{array}{c}\text { March } \\
\text { and April }\end{array}$ \\
\hline Chipps Island & 4.1 & $8.0(2.8)$ & $1.8(1.2)$ \\
\hline Suisun Bay & 6.1 & $12.4(2.9)$ & $6.9(0.8)$ \\
\hline Carquinez Strait & 8.1 & $19.4(2.8)$ & $14.2(0.4)$ \\
\hline San Pablo Bay & 12.5 & $27.7(1.0)$ & $24.7(2.0)$ \\
\hline South Bay & 28.5 & $30.6(1.1)$ & $27.1(2.1)$ \\
\hline
\end{tabular}

upstream station (Stn 4.1) at the mouth of the Sacramento River (station numbers are for long-term U.S. Geological Survey sampling stations; Fig. 1), where salinities ranged from 0.5 to $12.0 \%$, to the South Bay (Stn 28.5), where salinities ranged from 25.2 to $31.8 \%$. Thus, while temporal change was unusually stable for an estuary (Table 1), the spatial range of conditions, defined by the tolerances of this species, was broad.

\section{MATERIALS AND METHODS}

Metal uptake experiment. Metal uptake by an aquatic organism can be from solution, food, particulate material, sediments, or combinations of these (Luoma 1983, Luoma et al. 1990). One of these vectors, uptake of dissolved metal, was employed to test responsiveness of Potamocorbula amurensis to bioavailable metal. Uptake as a function of concentration was compared with that in the deposit feeding clam Macoma balthica. The 14 d uptake experiment was conducted at $10^{\circ} \mathrm{C}$ in sand-filtered seawater diluted with metal-free deionized water to $18 \%$ salinity. Two hundred individuals of $P$. amurensis and 160 individuals of $M$. balthica were collected from an intertidal mudflat at Martinez, California (near Stn 8.1; Fig. 1), on August 9, 1991 The clams were acclimated to the experimental conditions for $5 \mathrm{~d}$. Each species was divided into 6 treatment groups, 25 P. amurensis or 20 $M$. balthica per group. Each treatment employed clams encompassing the size range typical of the species in nature. Tissue was analyzed from one treatment group of each species after acclimation, but before the experiment. Another treatment group was kept in unspiked seawater throughout the experiment and analyzed after the experiment. The remaining 4 treatment groups were placed in individual tanks with 2 l of appropriately spiked seawater. A mixture of $\mathrm{Ag}, \mathrm{Cd}$ $\mathrm{Cu}$, and $\mathrm{Zn}$ was added to each of these tanks in concentrations corresponding to multiples of typical ambient concentrations found in San Francisco Bay water. The goal was to avoid concentrations of excessive metal exposure and to retain interelement ratios typical of the Bay. The baseline concentrations used were (in $\mu \mathrm{g} \mathrm{l}^{-1}$ ): $\mathrm{Ag}=0.1, \mathrm{Cd}=0.1, \mathrm{Cu}=2.0$, and $\mathrm{Zn}=5.0$ (Flegal et al. 1991, Smith \& Flegal 1993). Nominal metal spikes were 2, 5, 10, and 20 times these baseline values. $\mathrm{A} \mathrm{pH}$ of 8 was maintained throughout the experiment. The water was changed every $2 \mathrm{~d}$. No food or sediment was added. Clams that died were removed daily. At the end of $14 \mathrm{~d}$, clams were divided into 3 replicate size classes (small, medium, and large) from each experimental tank, soft tissues were removed and the clams were analyzed similarly to field samples. 
Field experiments. No interpretive approach can completely remove the intrinsic uncertainties in biosentinel data. However, certain statistical approaches can assess the importance of these uncertainties (variabilities). To determine the effect of clam size, a shell length versus concentration regression was used for each metal at each site. When there was a significant correlation, a concentration characteristic of the population was interpolated for a typical-sized clam $(15 \mathrm{~mm}$ shell length) and this value was used instead of the mean value (the mean assumes no size-metal concentration relationship). The error estimate was obtained from the regression.

To determine the effect of undigested material left in the digestive tract in Potamocorbula amurensis, clams from the same location and time were divided into 3 groups of 15 to 20 pooled individuals of similar shell length (within $1 \mathrm{~mm}$ ) and were either processed immediately after collection (without depuration). depurated for $48 \mathrm{~h}$, or depurated for $3 \mathrm{wk}$. To compare depuration with the complete removal of the digestive tract, another group of 15 to 20 pooled clams had their digestive tracts completely removed by dissection immediately after collection. The digestive tract was defined to include both the intestine and the digestive gland, which were both distinguished by their dark green/gray color. The whole tissue of the clams and the digestive tracts were analyzed separately.

Temporal variability was addressed by repeated sampling at the same sites over the 15 mo period. Three stations were sampled monthly from North San. Francisco Bay: Honker Bay (Stn 433), Carquinez Strait (Stn 8.1) and San Pablo Bay (Stn 12.5) (Fig. 1). Three additional sites were sampled every other month. These included Suisun Bay stations at Chipps Island (Stn 4.1) and Concord Naval Weapons Station (Stn 6.1), and one South Bay station at the San Mateo Bridge (Stn 28.5). Additional sites at Redwood Creek (Stn RC) and the San Joaquin River mouth (Stn SJR) were sampled once to compare the regional nature of interelement ratios in clams with suspected local inputs of contamination. The percent variability (coefficient of variation, CV) was used to indicate the magnitude of this variability.

Small-scale spatial/temporal interactions were assessed by comparing 2 types of adjacent environments (channel and mudflat) in July and September 1991. A period of low, stable river flow and consistent freshwater/seawater interface spanned both sampling periods. Two mudflat sites were sampled in Southampton Bay within $0.5 \mathrm{~km}$ of each other, and the channel site, Stn 8.1, was within $3 \mathrm{~km}$ from the mudflats (Fig. 1). Sites were chosen to avoid point source influence or other known localized confounding factors. The goals were to determine if the variability from one mudflat to another was greater than the variability within a mudflat, and to assess variability on a scale smaller than the large-scale, regional contamination gradient in the bay. Variability was defined by CVs calculated for mathematically pooled samples from the different monthly collections.

Large-scale contamination gradients in San Francisco Bay and their persistence through time were addressed by aggregating mean concentrations from the temporal sampling into a grand mean for each station. The mean concentrations were corrected for effect of clam size (as described above) and CVs were evaluated to characterize the large-scale variability

Sample collection. Samples from the subtidal zone were collected with a Van Veen grab. Channel depths ranged from 8 to $20 \mathrm{~m}$. One regularly sampled site in Honker Bay (Stn 433) (Fig. 1) was located in the shallows at an average depth of 1 to $3 \mathrm{~m}$. Between 60 and 120 clams of all sizes were collected from a $2 \mathrm{~mm}$ screen sieve at each time and each site and placed into containers of water collected at the site. The clams were kept in this ambient water in a constant-temperature room at $10^{\circ} \mathrm{C}$ to depurate for $48 \mathrm{~h}$, as previous studies showed a residence time of material in the gut of approximately $24 \mathrm{~h}$ in this species (Decho \& Luoma 1991). Clams from each site were separated into size classes of $1 \mathrm{~mm}$ difference and composite samples were made of similar sized individuals. Samples of larger numbers of individuals were necessary for smaller size classes in order to obtain enough mass for analysis. Mean concentrations characteristic of a site and at a particular time were thus determined from analyses of 5 to 14 replicate samples each containing 5 to 20 clams.

Sample preparation and analysis. Soft parts were removed from the shells and put into pre-weighed borosilicate glass scintillation vials. The samples were dried in an oven at $21^{\circ} \mathrm{C}$ to a constant weight ( 3 to $4 \mathrm{~d}$ ), then weighed. Concentrated nitric acid $\left(\mathrm{HNO}_{3}\right)$ was added to each vial to cover the tissue ( 3 to $5 \mathrm{ml}$ ). Each vial was covered with a reflux bulb, placed on a hotplate at approximately $38^{\circ} \mathrm{C}$, and the samples were digested by reflux until solutions were clear. They were then evaporated to dryness and reconstituted in $5 \%$ hydrochloric acid $(\mathrm{HCl})$. The amount of $\mathrm{HCl}$ added to the sample depended upon the total dry weight in the vial. Five ml was added to samples of less than $300 \mathrm{mg}$ and $10 \mathrm{ml}$ was added to samples greater than $300 \mathrm{mg}$. The samples were filtered with $0.45 \mu \mathrm{m}$ disposable filters after sitting for 2 to $3 \mathrm{~d}$. Concentrations of $\mathrm{Ag}, \mathrm{Cd}, \mathrm{Cr}, \mathrm{Cu}, \mathrm{Ni}, \mathrm{V}$, and $\mathrm{Zn}$ in the whole tissues of the clams were analyzed by Inductively Coupled Argon Plasma-Atomic Emission Spectroscopy (ICAPAES). 
Quality control. The ICAP-AES was standardized according to normal operating procedures. A standard was analyzed every 10 to 15 samples to ensure consistent performance of the instrument. The instrument limit of detection (LOD) and limit of quantitation (LOQ) were determined by 10 or more analyses of a blank throughout each analytical run. The mean and standard deviation (SD) of the values of the blank were calculated for each element. The LOD for each element was calculated by multiplying the SD by 3 and adding this value to the mean. The LOQ for each element was calculated by multiplying the SD by 10 and adding this to the mean. If the mean was a negative value, it was considered as zero. Data reported will be above the LOQ unless noted otherwise. Values of low precision (relative standard deviation $>10 \%$ ) are not used.

Analyses of National Institute of Standards and Technology (NIST) standard oyster tissue (no. 1566a) showed that all elements reported here fell within the error of the certified value of the standard reference material. Table 2 shows the detection limits for each of the metals measured and the measured and certified values of the NIST standard reference material.

Table 2. Method detection limits $\left(\mu \mathrm{g} \mathrm{ml}^{-1}\right)$ and certified and measured values $\left[\mu \mathrm{g} \mathrm{g}^{-1}\right.$ dry $\mathrm{wt}$, mean (SD)] of the oyster tissue standard reference material (NBS no. 1566a) for the metals analyzed in this study. $\mathrm{n}=23$ for measured values

\begin{tabular}{|c|c|c|c|}
\hline \multirow[t]{2}{*}{ Metal } & \multirow{2}{*}{$\begin{array}{c}\text { Detection } \\
\text { limit }\end{array}$} & \multicolumn{2}{|c|}{ Standard reference material } \\
\hline & & Certified value & Measured value \\
\hline $\mathrm{Ag}$ & 0.004 & $1.68(0.15)$ & $1.61(0.09)$ \\
\hline $\mathrm{Cd}$ & 0.004 & $4.15(0.38)$ & $4.38(0.21)$ \\
\hline $\mathrm{Cr}$ & 0.004 & $1.43(0.46)$ & $1.66(0.42)$ \\
\hline $\mathrm{Cu}$ & 0.033 & $66.30(4.30)$ & $66.88(3.14)$ \\
\hline $\mathrm{Ni}$ & 0.009 & $2.25(0.44)$ & $2.28(0.71)$ \\
\hline V & 0.003 & $4.68(0.15)$ & $4.52(0.14)$ \\
\hline $\mathrm{Zn}$ & 0.089 & $830.0(57.0)$ & $817.7(46.0)$ \\
\hline
\end{tabular}

\section{RESULTS}

\section{Response to metal exposure}

\section{Experimental uptake}

Potamocorbula amurensis responded proportionately to $\mathrm{Ag}, \mathrm{Cd}, \mathrm{Cu}$, and $\mathrm{Zn}$ concentrations in solution in the controlled uptake experiments. Net uptake of Ag, $\mathrm{Cd}, \mathrm{Cu}$, and $\mathrm{Zn}$ was a linear function of concentration $(p<0.05)$ after 14 d (Fig. 2). Total uptake of metals at each concentration was not always significantly different from that at adjacent concentrations (Fig. 2, insets), however there was a net accumulation over the full range of concentrations. The increase in uptake with

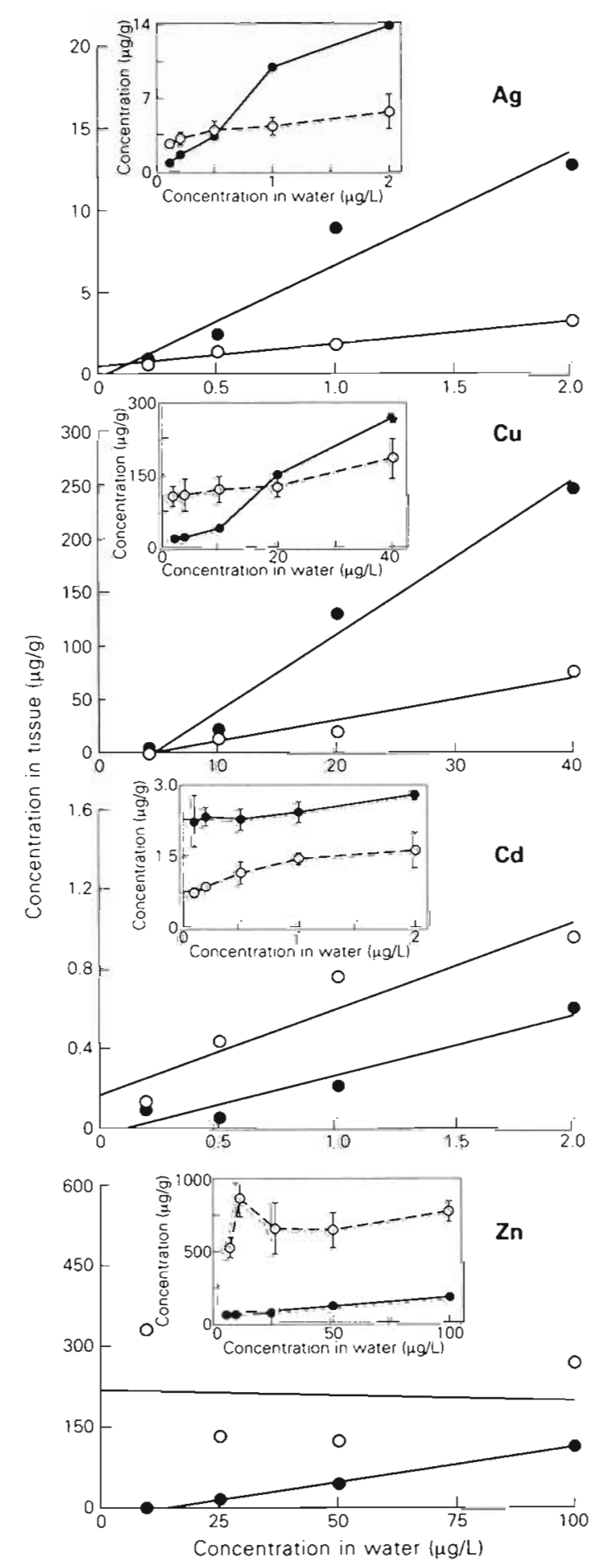

Fig. 2. Response of Potamocorbula amurensis (-) and Macoma balthica (O) to $\mathrm{Ag}, \mathrm{Cu}, \mathrm{Cd}$, and $\mathrm{Zn}$ concentrations in solution. The larger graphs show net accumulation (initial concentrations in the tissues subtracted from the final concentrations after $14 \mathrm{~d}$ exposure); concentrations are in $\mu \mathrm{g} \mathrm{g}^{-1}$ dry wt. The insets show the initial tissue concentrations $\left(\mathrm{ug} \mathrm{g}^{-1}\right.$ dry wt) and concentration of each metal after $14 \mathrm{~d}$ exposure (error bars = standard deviation) 
Table 3. (a) Measured minimum and maximum tissue concentrations ( $\mu \mathrm{g} \mathrm{g}^{-1} \mathrm{dry}$ wt) in Potamocorbula amurensis (including means) and Macoma balthica from San Francisco Bay. P. amurensis values were measured for this study. M. balthica data from D. J. Cain et al., U.S. Geological Survey (unpubl. data, 1980-1994). Cr, Ni, and V were not measured in $M$. balthica. (b) Comparison of tissue concentrations of metals $\left[\mathrm{g} \mathrm{g}^{-1}\right.$ dry wt; mean [SD]] in P. amurensis and $M$. balthica from the same location and time at a mudflat in Mart.nez, California

\begin{tabular}{|c|c|c|c|c|c|c|c|c|c|}
\hline & \multicolumn{7}{|c|}{ (a) San Francisco Bay } & \multicolumn{2}{|c|}{ (b) Martinez mudflat } \\
\hline & \multicolumn{4}{|c|}{ P. amurensis } & \multicolumn{3}{|c|}{ M. balthica } & \multirow[t]{2}{*}{ P. amurensis } & \multirow[t]{2}{*}{ M. balthica } \\
\hline & Min. & Max. & Mean (SD) & Max./Min. & Min. & Max. & Max./Min. & & \\
\hline $\mathrm{Ag}$ & 0.3 & 7 & $2.2\{1.4\}$ & 23 & 0.5 & 182 & 455 & $1.4(0.4)$ & $4.3(2.1)$ \\
\hline $\mathrm{Cd}$ & 1.4 & 10 & $3.9(1.9)$ & 7.1 & 0.1 & 0.5 & 5.0 & $3.6(0.4)$ & $1.2(0.2)$ \\
\hline $\mathrm{Cr}$ & 1.2 & 17 & $6.0(3.8)$ & 14 & & & & $6.2(1.5)$ & $8.2(2.3)$ \\
\hline $\mathrm{Cu}$ & 13 & 43 & $25.7(6.3)$ & 3.3 & 15 & 517 & 34 & $24.3(2.0)$ & $168(27)$ \\
\hline $\mathrm{Ni}$ & 2.8 & 23 & $8.4(3.8)$ & 8.4 & & & & $8.8(2.3)$ & $9.9(2.7)$ \\
\hline V & 0.7 & 9.4 & $3.1(2.0)$ & 14 & & & & $4.8(1.5)$ & $9.0(2.7)$ \\
\hline $\mathrm{Zn}$ & 58 & 141 & $92.4(18.4)$ & 2.4 & 93 & 865 & 9.3 & $97(5.7)$ & $756(262)$ \\
\hline
\end{tabular}

concentration followed the order $\mathrm{Ag}=\mathrm{Cu}>\mathrm{Zn} \geq \mathrm{Cd} . P$. amurensis responded more to changes in $\mathrm{Ag}, \mathrm{Cu}$, and Zn concentrations in solution than did Macoma balthica. The slope of $14 \mathrm{~d}$ uptake as a function of concentration in $P$. amurensis compared to $M$. balthica was 7.1 vs 2.0 for $\mathrm{Cu}$ and 6.9 vs 1.3 for $\mathrm{Ag}$. $P$. amurensis was less responsive to dissolved $Z n$ concentrations than to $\mathrm{Cu}$ or $\mathrm{Ag}$, but no response to $\mathrm{Zn}$ was observed in $M$. balthica. In contrast, $P$. amurensis and $M$. balthica responded similarly to changes in dissolved $\mathrm{Cd}$ concentrations.

Uptake in nature

The responsiveness of Potamocorbula amurensis to metals was assessed in nature by comparing the range of metal concentrations observed in different contamination conditions in San Francisco Bay (Fig. 1; Table 3a). Maximum and minimum tissue concentrations were compared in 126 samplings from 11 locations. It was assumed that a wide range indicated a strong ability of the clam to accumulate metals (Phillips 1985). These data probably do not include true reference concentrations for all metals, because of widespread, moderate-to-severe contamination in the bay. The greatest difference between maximum and minimum values in P. amurensis was observed for Ag (23 times) (Table 3a). The ratio of maximum to minimum concentrations of $\mathrm{Cd}, \mathrm{Cr}, \mathrm{Ni}$, and $\mathrm{V}$ ranged from 7 to 14 (Table $3 \mathrm{a}$ ). Maximum and minimum concentrations in $\mathrm{Zn}$ and $\mathrm{Cu}$ within this data set differed by only 2 to 3 times. Similar data among 298 observations of $\mathrm{Ag}, \mathrm{Cu}$, and $\mathrm{Zn}$ concentrations from 1.3 locations were compiled for Macoma balthica (Table 3a), which was used as a biosentinel by Cain \& Luoma (1990) and Luoma et al. (1990). The range of $\mathrm{Cd}$ concentrations was similar in the 2 species, but the range of $\mathrm{Ag}, \mathrm{Cu}$ and $\mathrm{Zn}$ concentrations was wider in $M$. balthica than in $P$. amurensis.

Tissue concentrations of metals were also compared between Potamocorbula amurensis and Macoma balthica collected from the same mudflat (Table $3 b$ ). Concentrations of $\mathrm{Ag}, \mathrm{Cd}, \mathrm{Cu}$ and $\mathrm{Zn}$ differed between the species, but not $\mathrm{Cr}, \mathrm{Ni}$, and $\mathrm{V}$. High $\mathrm{Cu}$ and $\mathrm{Zn}$ concentrations in $M$. balthica at this site indicated contamination. $P$. amurensis was less responsive than $M$. balthica to the $\mathrm{Cu}$ and $\mathrm{Zn}$ contamination. $M$. balthica was also the more responsive of the 2 species to $\mathrm{Ag}$ contamination, and $P$. amurensis the most responsive to $\mathrm{Cd}$.

The bioaccumulation differences between Potamocorbula amurensis and Macoma balthica in nature were not consistent with the results of the dissolved metal uptake experiment. $\mathrm{Ag}, \mathrm{Cu}$, and $\mathrm{Zn}$ concentrations were higher in $M$. balthica than in $P$. amurensis in nature. However, bioconcentration of all 3 was greatest in $P$. amurensis in the laboratory. Cd concentrations were higher in $P$. amurensis than in $M$. balthica from the same mudflat (ca 3 times), but uptake from solution in the laboratory was similar in the 2 species.

\section{Effects of biological factors on metal concentrations}

\section{Gut content}

The content of the digestive tract had an effect on whole tissue concentrations of some, but not all, metals in Potamocorbula amurensis (Fig. 3). Concentrations of $\mathrm{Cr}, \mathrm{Cu}, \mathrm{Ni}$, and $\mathrm{V}$ were significantly higher if clams were not depurated. Concentrations of $\mathrm{Cr}, \mathrm{Cu}, \mathrm{Ni}$, and $V$ were higher in the intestine alone and in the sediments than in the tissues. Concentrations of $\mathrm{Ag}, \mathrm{Cd}$, and $\mathrm{Zn}$ were not different between the depurated and 
Fig. 3. Potamocorbula amurensis. Effect of depuration and gut content on metal concentrations ( $\mathrm{\mu g} \mathrm{g}^{-1}$ dry $w t)$ in tissue of clams collected from the field. Typical concentrations of the metals in sediments ( $\mu \mathrm{g} \mathrm{g}^{-1} \mathrm{dry}$ wt) in San Francisco Bay are indicated in parentheses. Sediment data from M. Hornberger, U.S. Geological Survey (unpubl. data). Note scale break at $65 \mathrm{\mu g} \mathrm{g}^{-1}$

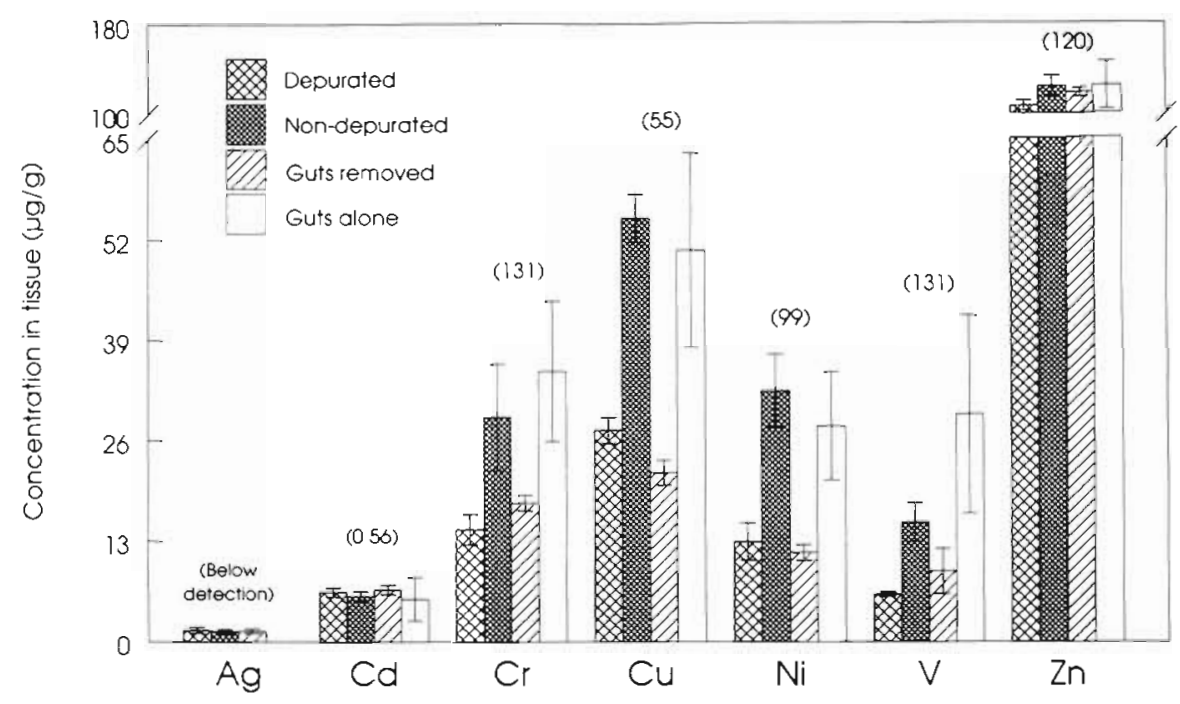

non-depurated groups. The sediment concentrations of $\mathrm{Ag}, \mathrm{Cd}$, and $\mathrm{Zn}$ were less than or equal to the tissue concentrations in the depurated clams. Thus the bias from undigested gut content was only significant for those elements enriched in sediments relative to tissues. There was also no significant difference between depuration for $48 \mathrm{~h}$ and $3 \mathrm{wk}$, so physiological loss was not a significant factor in depuration.

\section{Effects of clam size}

Concentrations of most elements were only occasionally correlated significantly $(p<0.05)$ with length or weight of Potamocorbula amurensis. At most sampling times or locations the correlations were insignificant. Ag and $\mathrm{Cr}$ had the highest frequency of significant correlations. The frequency of significant correlations between Ag and length was greater at the more contaminated sites than at the less contaminated sites (Fig. 4). Typical relationships between Ag and length for 3 consecutive months in 1991 illustrate how the correlation with size differed with space and time (Fig. 5). P. amurensis populations differed widely in size range and abundance. However, overall, it was possible to consistently separate, or rank, stations by the degree of Ag contamination by sampling the widest possible range of sizes. In some months the size range at a site was too limited, or the number of replicates too small, to detect a correlation with size. Consistently sampling one size everywhere was not always feasible and would not have improved interpretations.

Cr concentrations were also related to size in a complex fashion (Fig. 6). In typical collections, 'larger' size classes had higher concentrations of $\mathrm{Cr}$ than 'smaller' size classes. The break between high and low $\mathrm{Cr}$ con- centrations occurred at different shell lengths at different sites (Fig. 6). Sampling a wide size range allowed ranking of sites; it is conceivable the ranking could be affected by a highly skewed sampling, but that was not a common occurrence. Sampling a single size class would have resulted in greater uncertainty about representative $\mathrm{Cr}$ concentrations than did sampling a wide size range.

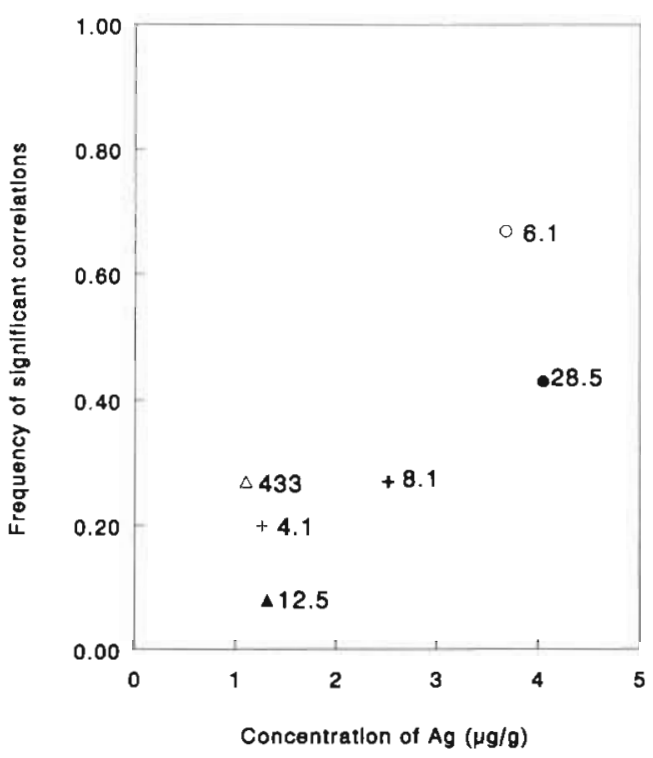

Fig. 4. Potamocorbula amurensis. Proportion (frequency) of significant correlations ( $\mathrm{p}>0.05$ ) between shell length and $\mathrm{Ag}$ concentrations in tissues of individual clams ( $\mu \mathrm{g} \mathrm{g}^{-1}$ dry wt) as a function of mean Ag concentration in tissues at each station (station numbers are shown next to each symbol). Mean tissue concentration was calculated from all samples collected between January 1991 and March 1992 

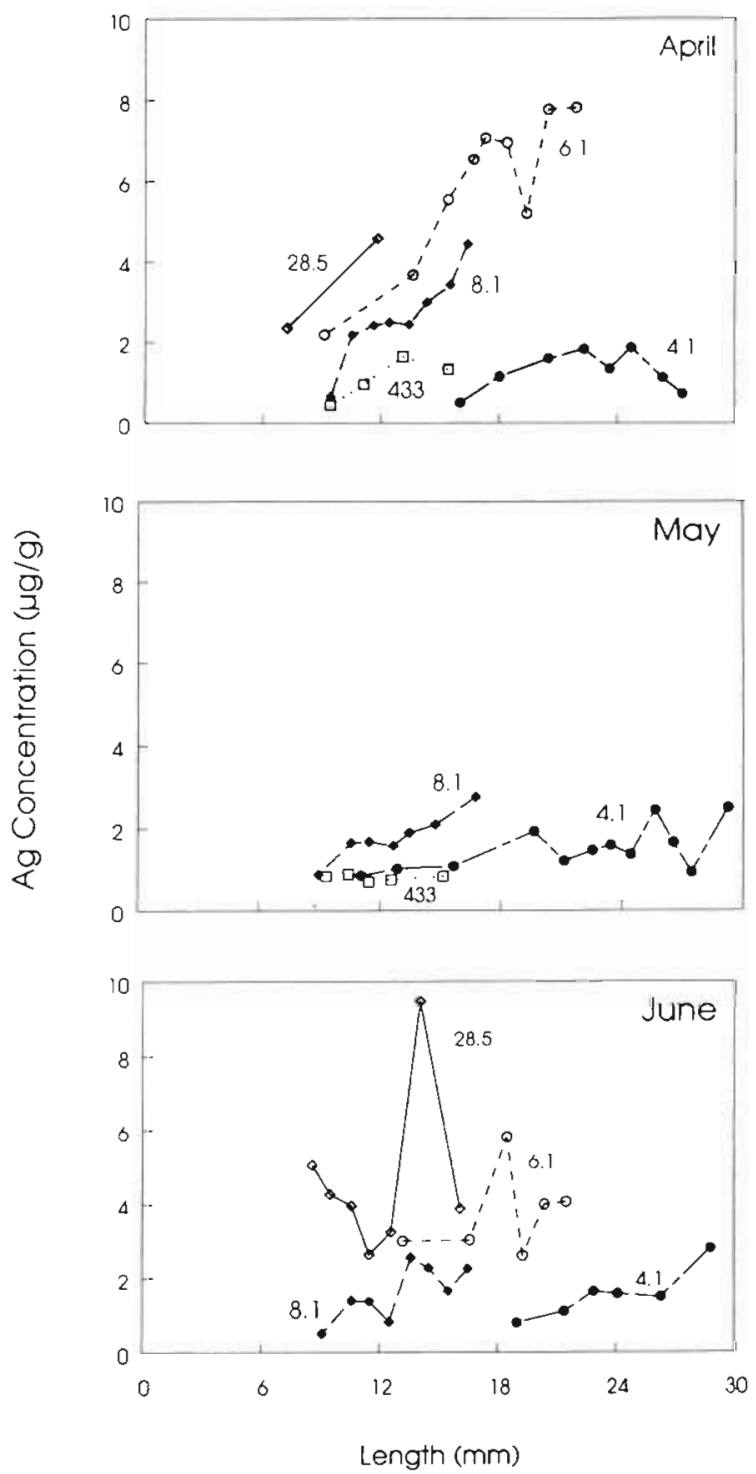

Fig. 5. Potamocorbula amurensis. Ag concentrations $\left(\mu \mathrm{g} \mathrm{g}^{-1}\right.$ dry wt) in the tissue of clams related to shell length at each station sampled during April, May, and June 1991. Station numbers are shown next to each plotted line

\section{Sources of variability in metal concentrations}

\section{Sample variability}

The absolute value of the standard deviation among samples in a monthly collection increased slightly with metal concentration (Fig, 7). The CV was relatively constant for each metal, but it differed among metals. Large CVs for $\mathrm{Cr}$ and Ag occurred because mean concentrations were frequently affected by the mean size of the clams that made up the collection (i.e. these were not normally distributed values) (Figs. $5 \& 6$ ). To

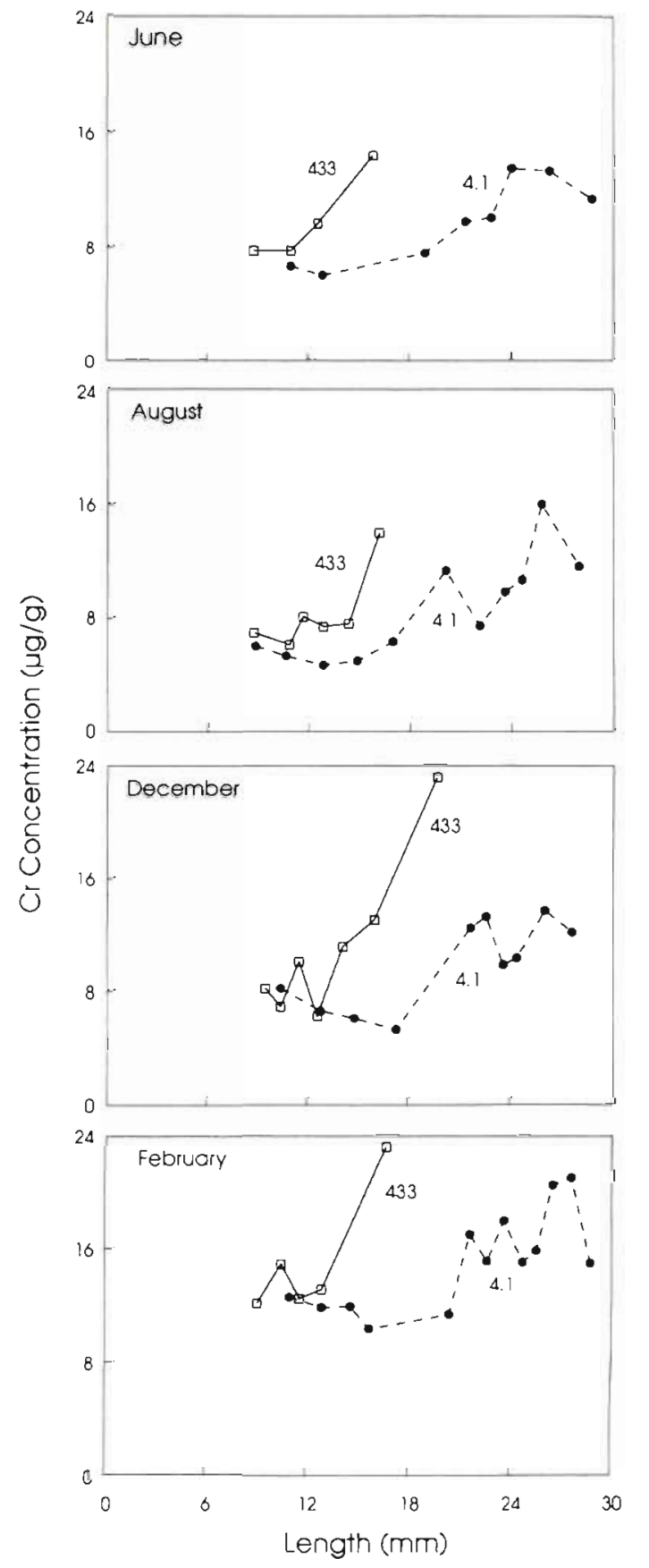

Fig. 6. Potamocorbula amurensis. Cr concentrations $\left(\mu \mathrm{gg} \mathrm{g}^{-1}\right.$ dry wt) in the tissue of clams related to shell length at Stns 433 and 4.1 (Fig. 1) in June, August, and December 1991 and February 1992. All relationships are significantly correlated $(p>0.05)$

compensate for size, one 'typical-sized clam' was defined for the entire bay (mid-sized, $15 \mathrm{~mm}$ shell length). The metal concentrations describing a population were determined by interpolating the concentration in the 'typical-sized clam' from the size-concentration regression. The error (variability) associated with 

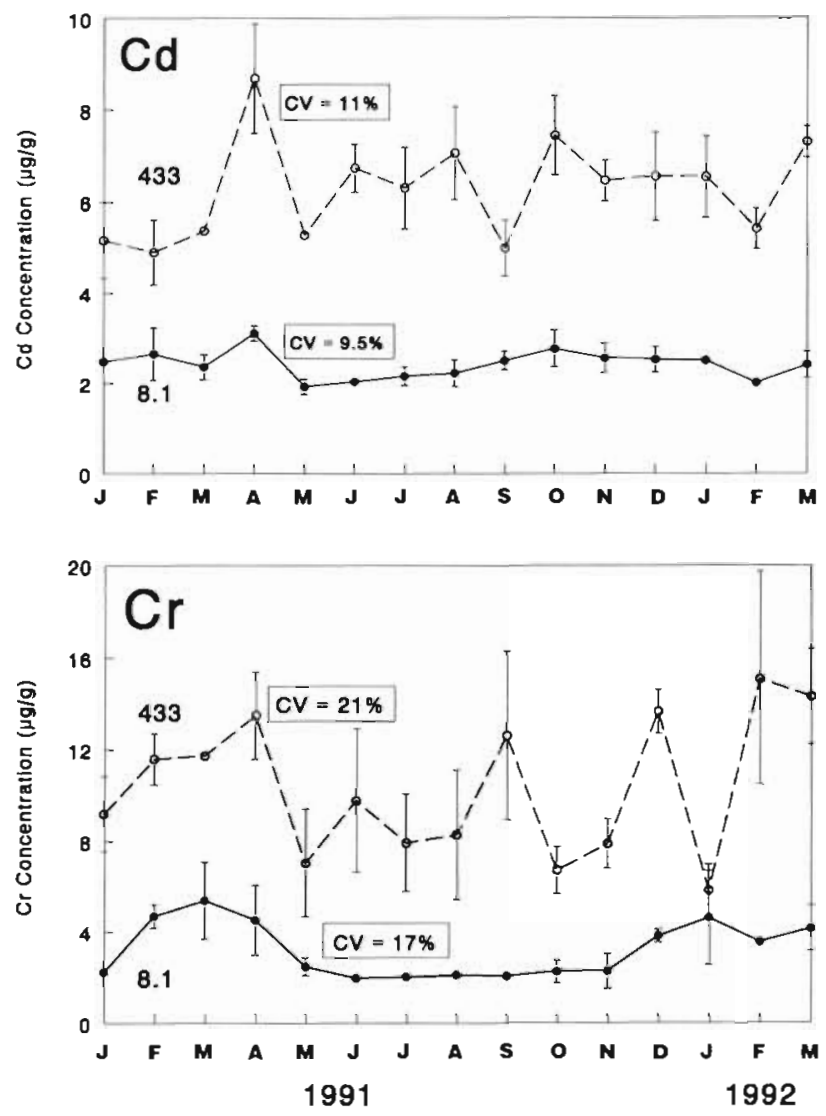

Fig. 7. Potamocorbula amurensis. Within-site variability of $\mathrm{Cd}$ and $\mathrm{Cr}$ tissue concentrations ( $\mu \mathrm{g} \mathrm{g}^{-1} \mathrm{dry}$ wt) in clams at a more variable site (Stn 433 ) and a less variable site (Stn 8.1) (see Fig. 1). $C V$ is the average coefficient of variation ( $S D \times 100 /$ meanj among all collections. Each data point represents the mean of the pooled samples for each month. Data has been corrected for any effect of size. Error bars are $1 \mathrm{SD}$ from the mean

this estimate was determined from the regression. As expected, this error was less than the standard deviation around the mean. For example, the CV around the mean $\mathrm{Cr}$ concentration at Stn 433 was $52 \%$ in December 1991 . The variation estimated from the significant size vs concentration relationship at that time was $7 \%$

The average CV among the 15 collections for mean Cd was $17 \%$ at $\operatorname{Stn} 433$ and $13 \%$ at Stn 8.1 , and the average CV for mean Cr was 28 and $27 \%$ at Stns 433 and 8.1 , respectively. If an interpolated metal concentration was used whenever a significant size relationship occurred, the average $\mathrm{CV}$ for Cd among the 15 collections was 11 and $9.5 \%$ for Stns 433 and 8.1 , respectively (Fig. 7). Significant size relationships with Cd were found in 1 collection at Stn 433 and in 3 collections at $\mathrm{Stn}$ 8.1. The average $\mathrm{CV}$ for $\mathrm{Cr}$ among the 15 collections was 21 and $17 \%$ at Stns 433 and 8.1, respectively, when the size correction was employed.
Significant size relationships with $\mathrm{Cr}$ were found in 1 collection at Stn 433 and in 8 collections at Stn 8.1. Thus by collecting a wide range of sizes, and correcting for size effects when they were significant, a relatively small variance was achieved in the value describing metal concentrations in populations of Potamocorbula amurensis.

\section{Small-scale spatial variability}

Metal concentrations were not significantly different between clams at the mudflat and the channel station in July 1991 (Fig. 8). In September, metal concentrations in clams from 2 adjacent mudflats were not significantly different, but concentrations of some ele-

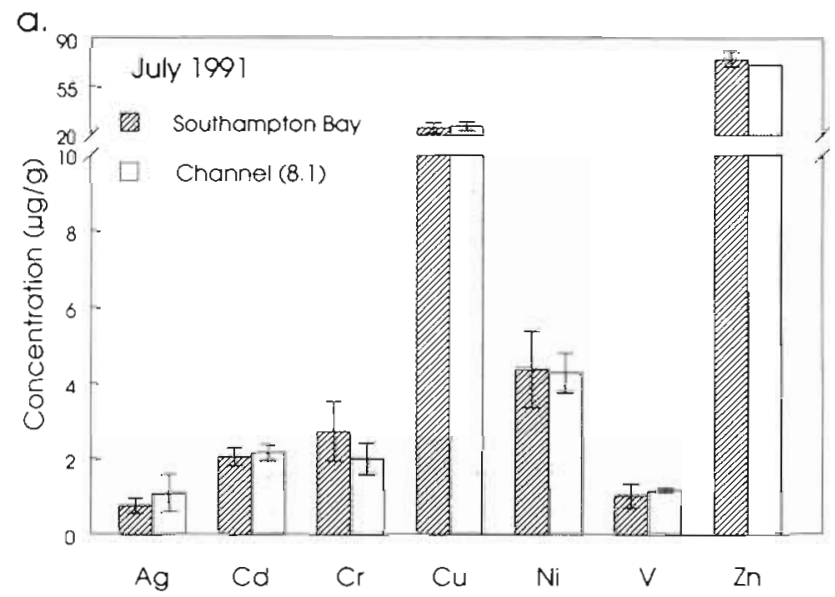

b.

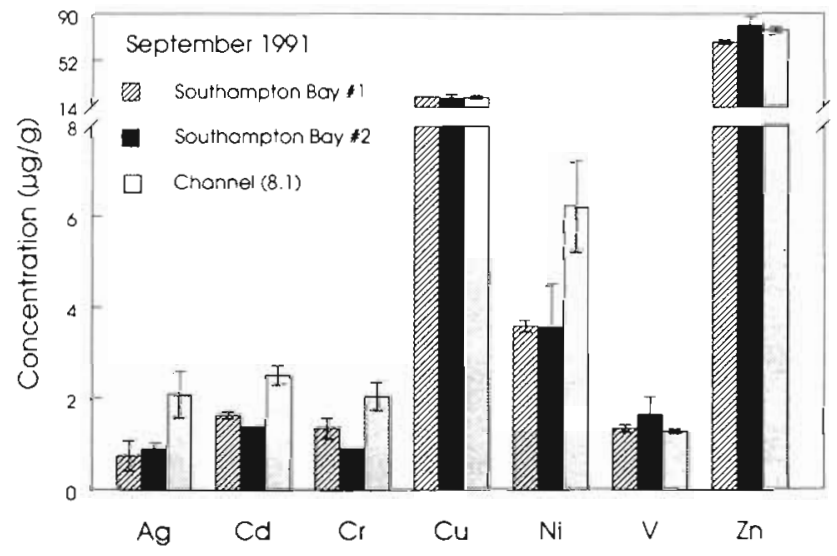

Fig. 8. Potamocorbula amurensis. Tissue concentrations ( $\mathrm{\mu g}$ $\mathrm{g}^{-1}$ dry wt) in clams at 3 locations along a $3 \mathrm{~km}$ cross-bay transect. Samples were collected at the same time to compare small-scale spatial variability in adjacent mudflats and the channel station (Stn 8.1). (a) Comparison of mudflat at Southampton Bay and the channel station (Stn 8.1) in July 1991 (see Fig. 1). (b) Comparison of 2 adjacent mudflats in Southampton Bay and the channel station in September 1991 
Table 4. Coefficient of variation (CV) for Cd concentrations in Potamocorbula amurensis samples from channel (Stn 8.1) and 2 Southampton Bay mudflat locations $(3 \mathrm{~km}$ from Stn 8.1; Fig. 1) comparing different spatial/ temporal interactions

\begin{tabular}{|lccc|}
\hline Sample site & Month & Interaction & CV for Cd \\
\hline Channel & Jul and Sep 1991 & Temporal & $11.3 \%$ \\
Two mudflats & Sep 1991 & Spatial & $18.3 \%$ \\
Two mudflats & Jul and Sep 1991 & Spatial/temporal & $19.4 \%$ \\
Channel/mudflat & Jul 1991 & Spatial & $10.1 \%$ \\
Channel/mudflat & Sep 1991 & Spatial & $25.5 \%$ \\
Channel/mudflat & Jul and Sep 1991 & Spatial/temporal & $20.7 \%$ \\
Channel & Jan 1991 to Mar 1992 & Temporal & $13 \%$ \\
Channel & Jan 1991 to Mar 1992 & Size-Corrected & $9.5 \%$ \\
& & & \\
\hline
\end{tabular}

All monthly collections during the period of study showed a consistent spatial contamination gradient and ranking of metals: $\mathrm{Ni}>\mathrm{Cr}>\mathrm{Cd}=\mathrm{V}$. The grand mean concentrations showed a similar gradient, indicating that this contamination was a permanent characteristic of the estuary during this period. The contamination with $\mathrm{Cd}, \mathrm{Cr}, \mathrm{Ni}$, and $\mathrm{V}$ was high near the river mouth (the upstream-most end of the range of Potamocorbula amurensis) and declined into Stn 12.5 (Fig. 9). The data consistently showed that the station with the highest concentrations of these elements was Stn 433, some

ments (Ag, Cd, Cr, Ni) were significantly higher in the channel clams than in the mudflat clams.

The CVs for samples from the mudflats and channel were mathematically pooled in order to test how the $\mathrm{CV}$ of a combined sample changed with different aspects of the space and time interaction (Table 4). Data are given for $\mathrm{Cd}$, because the pools could be constructed with minimal interacting effects of clam size. Variability on the mudflats was nearly 2 -fold greater than variability in the channel whether in an individual sampling or when July and September data were combined. Thus when channel and mudflat data were combined at one time, or at both samplings, the $\mathrm{CV}$ was about 2 -fold greater than the average $\mathrm{CV}$ at the channel over the 15 months.

The effect of small-scale spatial effects and the time effect on power (sensitivity) were small. Assuming a sample size of 10 , a mean Cd concentration of $3 \mu_{\mathrm{g} \mathrm{g}}{ }^{-1}$, and a standard deviation of $25 \%$ (the greatest variability in the pooled data), a difference of $0.9 \mu \mathrm{g} \mathrm{g}^{-1} \mathrm{Cd}$ could be detected ( $p<0.05$ ) (power calculation from Zar 1984). At a standard deviation of $11 \%$ (the least variability), a difference of $0.6 \mu \mathrm{g} \mathrm{g}^{-1}$ would be detectable. Thus, the small-scale spatial/temporal variability reduced the power of the biosentinel data to detect a change by only $0.3 \mu \mathrm{g} \mathrm{g}^{-1} \mathrm{Cd}$ or $10 \%$ of the mean.

\section{Large-scale variability}

The CVs of the grand mean Cd concentrations at Stns 8.1 and 433 were 3.3 and $4.3 \%$, respectively. The CVs for the grand mean Cr concentrations were 12.4 and $7.3 \%$, respectively. Thus, the estimates of the spatial distribution of contamination obtained from the grand mean concentrations were slightly more sensitive than the mean obtained in an average sampling period (CVs of size-corrected data reported earlier; Fig. 7). distance from any known source of metal input. This may be an area of hydrodynamic focusing of biologically available metal contaminants. $P$. amurensis were not as enriched in $\mathrm{Cu}$ and $\mathrm{Zn}$ in upper Suisun Bay as they were in $\mathrm{Cd}, \mathrm{Cr}, \mathrm{Ni}$, and $\mathrm{V}$. This probably reflected the poor responsiveness of $P$. amurensis to these metals in the ecosystem, since earlier studies showed $\mathrm{Cu}$ contamination was comparable to other metals (Luoma et al. 1990).

An increase in Ag in mid-Suisun Bay was consistently detected, suggesting a 'hot-spot' of this metal. Ag concentrations in Potamocorbula amurensis were also detectably enriched in the South Bay (Stn 28.5). The Ag gradient was different from the gradients seen in the other metals described above.

In a comparison of different regions of the estuary, the upper reaches of Suisun Bay, the lower reach of Suisun Bay, and the South Bay each had distinct metal signatures (Fig. 10). This was probably because the regions differ in sources (and type) of contamination, salinity, and circulation. Upper Suisun Bay clams were always enriched in $\mathrm{Cr}$ and had low Ag concentrations. Lower Suisun Bay clams (Stns 6.1 and 8.1) were moderately emriched in $\mathrm{Cr}$ and $\mathrm{Ag}$, with $\mathrm{Cr}$ concentrations greater than Ag concentrations. South Bay clams, including a station in Redwood Creek (Stn RC) (which was sampled once as a comparison), were enriched in Ag and had little $\mathrm{Cr}$ contamination.

\section{DISCUSSION}

Potamocorbula amurensis was an effective biosentinel for $\mathrm{Ag}, \mathrm{Cd}, \mathrm{Cr}, \mathrm{Ni}$, and $\mathrm{V}$ in San Francisco Bay. The clam responded to changes in concentrations of dissolved metal in the laboratory and accumulated Ag. $\mathrm{Cd}, \mathrm{Cr}, \mathrm{Ni}$, and $\mathrm{V}$ in the bay. Tissue concentrations in $P$. amurensis consistently indicated a distinct contamination gradient through the North Bay, parts of which had been noted in earlier determinations of environ- 

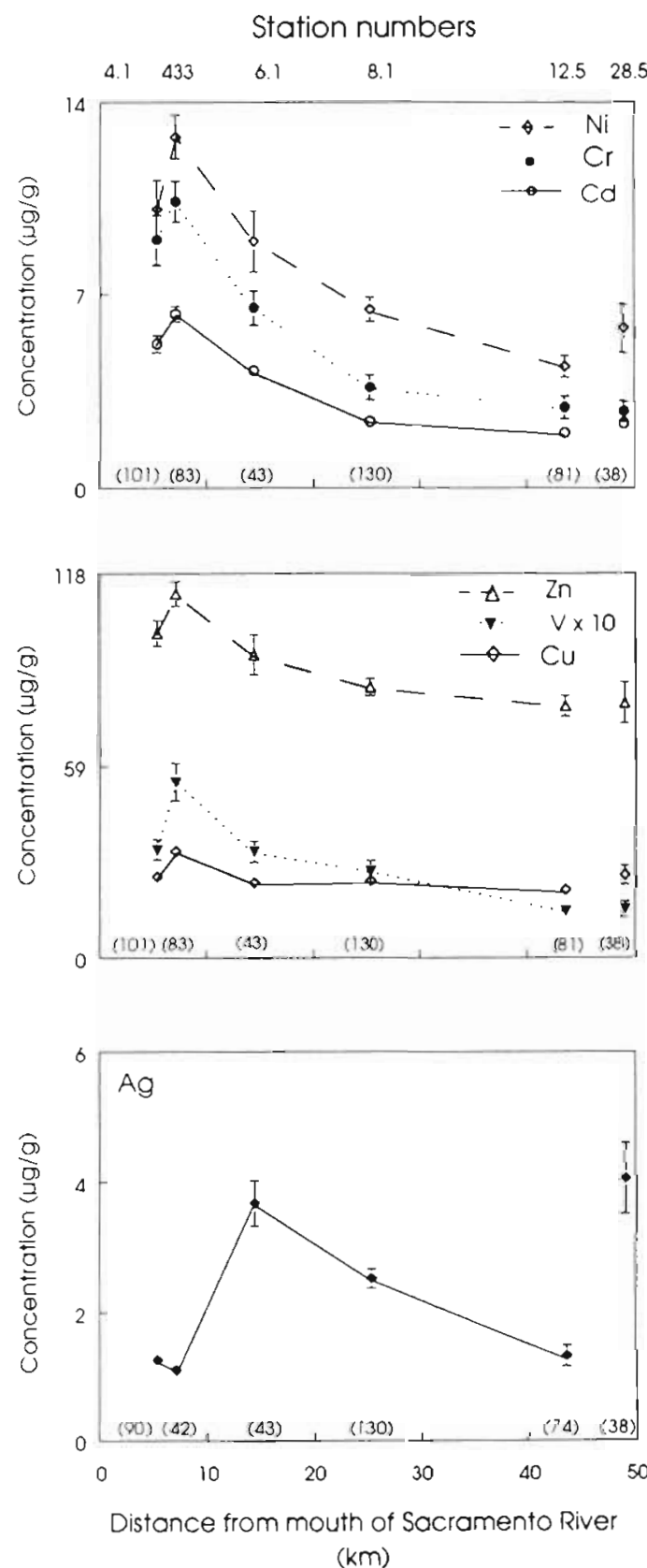

Fig. 9. Potamocorbula amurensis. Grand means of tissue concentrations ( $\mathrm{kg} \mathrm{g} \mathrm{g}^{-1} \mathrm{dry}$ wt) in clams showing large-scale contamination gradient downstream through north San Francisco Bay and in the South Bay. Numbers in parentheses are the number of samples to produce the grand mean. Error bars are the standard error of the mean. Values are 10 times actual values

mental contamination in Suisun Bay in water, sediment, and freshwater clams (Luoma \& Phillips 1988, Luoma et al. 1990, Flegal et al. 1991). The gradient was less distinguishable in earlier bioindicator studies because of the restriction of the clam Corbicula fluminea to the lowest salinities in the estuary.

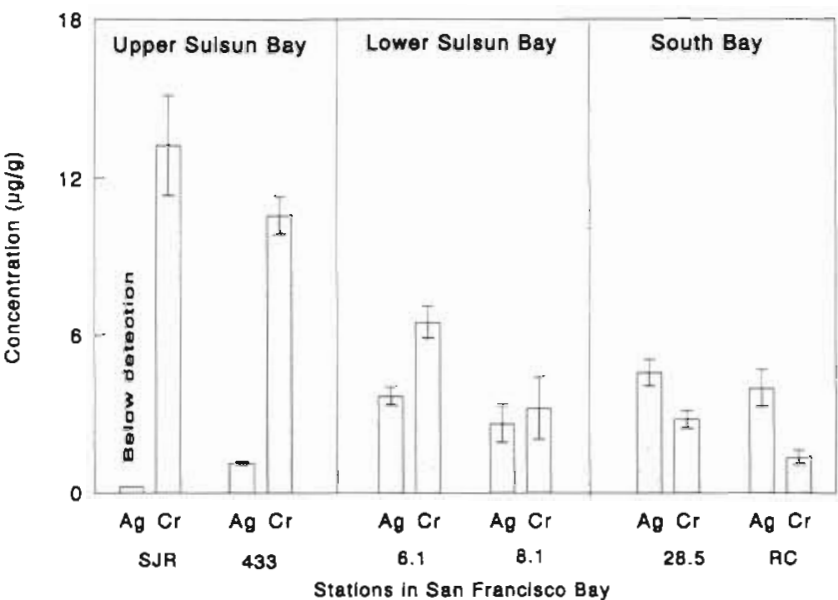

Fig. 10. Potamocorbula amurensis. Tissue concentrations ( $\mu \mathrm{g}$ $\mathrm{g}^{-1}$ dry wt) of $\mathrm{Ag}$ and $\mathrm{Cr}$ in clams from 3 regions in San Francisco Bay with distinct contamination signatures. SJR is a site in the San Joaquin River and RC is a site in Redwood Creek (see Fig. 1), both of which were sampled once for comparison to sites sampled monthly

Because of the broad range of Potamocorbula amurensis, it was possible to distinguish different contamination characteristics in South Bay and Suisun Bay, based on $\mathrm{Cr}$ and $\mathrm{Ag}$ signatures. The Ag enrichment in the clams in the South Bay was consistent with Ag contamination in solution (Smith \& Flegal 1993) and sediment (Luoma \& Phillips 1988). The high Cr concentrations in $P$. amurensis in the upper Suisun Bay were consistent with $\mathrm{Cr}$ contamination reported for Corbicula fluminea and large inputs of $\mathrm{Cr}$ from a steel plant that occur in this region (Gunther et al. 1987, Luoma et al. 1990)

Potamocorbula amurensis was less useful as a biosentinel for $\mathrm{Zn}$ and $\mathrm{Cu}$. Martincic et al. (1984) contrasted concentration factors for $\mathrm{Cd}, \mathrm{Cu}_{\text {, }}$ and $\mathrm{Zn}$ between mussels Mytilus galloprovincialis and oysters Ostrea edulis, in the Adriatic Sea. P. amurensis is a slightly more sensitive bioindicator for $\mathrm{Cu}$ than are mussels, based on concentration factor comparisons (Table 5). Others have also reported the limited responsiveness of mussels to $\mathrm{Cu}$ (Goldberg et al. 1983, Smith et al. 1986). Oysters are more than 5 times more responsive to $\mathrm{Cu}$ than either $P$. amurensis or $M$. galloprovincialis (Table 5). The concentration factor comparison also supports the contention that $P$. amurensis concentrates Cd strongly.

The concentration factors and responsiveness observed in nature were not completely consistent with dissolved metal uptake in the laboratory. Zn was accumulated in only a narrow range of concentrations in nature and a slow bioaccumulation was observed in the laboratory. Potamocorbula amurensis accumulated $\mathrm{Cu}$ rapidly from solution in the laboratory and more 
Table 5. Dissolved metal concentrations $\left(\mu \mathrm{g} \mathrm{l}^{-1}\right)$ in San Francisco Bay and concentration factors for Potamocorbula amurensis compared to concentration factors for Mytilus galloprovincialis and Ostrea edulis from Martincic et al. (1984). The concentration factor is the ratio of mean tissue concentration ( $\mu \mathrm{g} \mathrm{g}^{-1} \mathrm{dry}$ wt) (Table 3 ) to mean water concentration $\left(\mu \mathrm{g} \mathrm{I}^{-1}\right.$ )

\begin{tabular}{|c|c|c|c|c|c|c|}
\hline & \multicolumn{2}{|c|}{ San Francisco Bay water } & \multirow[t]{2}{*}{ Water data source } & \multicolumn{3}{|c|}{ Concentration factors } \\
\hline & Range & Mean (SD) & & P. amurensis & M. galloprovincialis & O. edulis \\
\hline $\mathrm{Ag}$ & $0.001-0.026$ & $0.006(0.005)$ & Smith \& Flegal (1993) & 386000 & & \\
\hline $\mathrm{Cd}$ & $0.01-0.17$ & $0.08(0.04)$ & Flegal et al. (1991) & 50200 & 9100 & 30400 \\
\hline $\mathrm{Cr}$ & $0.09-0.43$ & $0.17(0.10)$ & Abu-Saba \& Flegal (1995) & 36600 & & \\
\hline $\mathrm{Cu}$ & $0.54-4.64$ & $2.05(0.76)$ & Flegal et al. (1991) & 12200 & 4000 & 64500 \\
\hline $\mathrm{Ni}$ & $0.59-4.17$ & $1.63(0.65)$ & Flegal et al. (1991) & 5200 & & \\
\hline v & No data & No data & & & & \\
\hline $\mathrm{Zn}$ & $0.23-1.83$ & $0.80(0.36)$ & Flegal et al. (1991) & 115500 & 95000 & 95500 \\
\hline
\end{tabular}

rapidly than Macoma balthica, an excellent $\mathrm{Cu}$ bioindicator in nature (Bryan et al. 1980, 1985), but the range of tissue concentrations in $P$. amurensis was narrow in Suisun Bay, where earlier studies indicated $\mathrm{Cu}$ contamination was common (Thomson et al. 1984, Cain \& Luoma 1990, Luoma et al. 1990). Cu concentrations were also much lower in $P$. amurensis than in $M$. balthica when they were compared at a Cu-contaminated mudflat. The laboratory experiments only represent a single vector of uptake. Nevertheless, they suggest that $P$. amurensis does not necessarily regulate $\mathrm{Cu}$, but that behavioral or ecological characteristics or variable pathways affect its exposure to the metal in nature. Phillips \& Rainbow (1989) emphasized that bioaccumulation strategies vary from species to species and metal to metal within a species. However, they implied that such strategies were the result of inherent physiological properties of the organisms involved. Data from $P$. amurensis suggest that avoidance of metal exposure by organisms physiologically capable of bioaccumulation should also be included among such 'strategies'.

Biomonitoring has been criticized because of the variability inherent in tissue concentrations of contaminants (Lobel 1987, Lobel et al. 1989). The simplest approaches may not yield repeatable results, but variability can be reduced to manageable levels with careful methodologies (Metcalfe-Smith 1994). Useful sampling strategies in San Francisco Bay included collection of large numbers of individuals, analyzing a number of replicated composite samples within which similar-sized animals were combined, and repeated samplings at each site. Depuration of undigested gut content was essential in Potamocorbula amurensis. Serious biases otherwise resulted, in particular for those metals which occurred in high concentrations in sediments, compared to tissues.

Effects of animal size on metal concentration must be considered to prevent bias in bioindicator data. These effects were inconsistent in Potamocorbula am- urensis, partly because of the unstable population dynamics. Size structure differs widely between populations and variability in both abundance and periods of rapid growth is common (Thompson \& Nichols 1995). It was not a viable option to collect animals of one size from a number of locations, or even from one location through time. Sampling only one size class would have reduced the number of individuals in each sample, and resulted in omitting sample collections at some times and places. As an alternative, the widest possible range of sizes was collected at each time and place, and composite samples were formed from similar-sized individuals. The correlation between size and metal concentration was used to correct mean concentrations and reduce the variability associated with that mean when a significant correlation of concentration with size was observed. Mean concentrations were replaced with the concentration interpolated from the correlation for a mid-sized clam (15 $\mathrm{mm})$, and variance was estimated from the regression. All individuals in the sample were employed in estimates from a significant regression, minimizing the variance in the estimate of mean concentration. In cases where no relationship occurred between size and concentration, the mean concentration of the entire sample collection was used. This strategy allowed the comparison of populations with wide ranging size structures. It could also be useful in species with more stable population dynamics.

Variability on different scales should also be quantified, at least as an initial step, in studies of the applicability of the biosentinel approach to an ecosystem. Temporal variability was small in San Francisco Bay for the period of this study, probably because of the relatively stable river inflow caused by drought. Repeated sampling of individual sites was less important than it might be under more variable estuarine conditions. Small-scale spatial variability was also a relatively small source of uncertainty. Contamination at one location appeared to be representative of contamination at 
adjacent locations (within a few kilometers and in the absence of localized inputs).

Biological and ecological characteristics are an essential consideration for a biosentinel. Potamocorbula amurensis is an effective biosentinel for studying processes controlling trace element contamination and bioavailability in San Francisco Bay because it is found throughout the bay, has an unusually wide salinity tolerance and is sensitive in indicating environmental differences in trace metal uptake

These initial studies defined the responsiveness of Potamocorbula amurensis to changes in exposure to specific metals. The accuracy of the response was verified by consistency with data from other studies in the bay and in the laboratory. The precision of the response was determined and strategies were suggested to minimize inherent variability and thus increase precision. Like any assessment tool, demonstration of responsiveness, accuracy and precision should be a prerequisite for the optimal use of biosentinels in any ecosystem.

Acknowledgments. Thanks to Francis Parcheso, Byron Richards, Scott Conard, and Jan Thompson for advice and field expertise throughout the study. Jan Thompson, Dan Cain, and Linda Anderson made valuable comments on the manuscript.

\section{LITERATURE CITED}

Abu-Saba KE, Flegal AR (1995) Chromium in San Francisco Bay: superposition of geochemical processes causes complex spatial distributions of redox species. Mar Chem (in press)

Beasely EL, Hiller MA, Biggs RB (1988) Susceptibility of U.S. estuaries to pollution. Wat Sci Technol 20:211-219

Borchardt T, Burchert S, Hablizel H, Karbe L, Zeitner R (1988) Trace metal concentrations in mussels: comparison between estuarine, coastal and offshore regions in the southeastern North Sea from 1983 to 1986. Mar Ecol Prog Ser 42:17-31

Boyden CR, Phillips DJH (1981) Seasonal variation and inherent variability of trace elements in oysters and their implications for indicator studies. Mar Ecol Prog Ser 5:29-40

Bryan GW (1976) Some aspects of heavy metal tolerance in aquatic organisms. In: Lockwood APM (ed) Effects of pollutants on aquatic organisms. Cambridge University Press, Cambridge, p 7-34

Bryan GW, Hummerstone LG (1978) Heavy metals in the burrowing bivalve Scrobicularia plana from contaminated and uncontaminated estuaries. J mar biol Ass UK 58: 401-419

Bryan GW, Langston WJ, Hummerstone LG (1980) The use of biological indicators of heavy metal contamination in estuaries. J mar biol Ass UK Occ Publ No 1:1-73

Bryan GW, Langston WJ, Hummerstone LG, Burt GR (1985) A guide to the assessment of heavy-metal contamination in estuaries using biological indicators. J mar biol Ass UK Occ Publ No 4:1-92

Bryan GW, Langston WJ, Hummerstone LG, Burt GR, Ho YB (1983) An assessment of the gastropod, Littorina littorea, as an indicator of heavy-metal contamination in United Kingdom estuaries. J mar biol Ass UK 63:327-345

Bryan GW. Uysal H (1978) Heavy metals in the burrowing bivalve Scrobicularia plana from the Tamar Estuary in relation to environmental levels. J mar biol Ass UK 58: $89-108$

Cain DJ, Luoma SN (1990) Influence of seasonal growth, age, and environmental exposure on $\mathrm{Cu}$ and $\mathrm{Ag}$ in a bivalve indicator, Macoma balthica, in San Francisco Bay. Mar Ecol Prog Ser 60:45-55

Campbell PGC, Lewis AG, Chapman PM, Crowder AA, Fletcher WK, Imber B, Luoma SN, Stokes PM, Winfrey M (1989) Biologically available metals in sediments. National Research Council of Canada, Division of Chemistry Publication, Ottawa

Carlton JT, Thompson JK, Schemel LE, Nichols FH (1990) Remarkable invasion of San Francisco Bay (California, USA) by the Asian clam Potamocorbula amurensis. I. Introduction and dispersal. Mar Ecol Prog Ser 66:81-94

Conomos TJ, Smith RE, Gartner JW (1985) Environmental setting of San Francisco Bay. Hydrobiologia 129:1-12

Decho AW, Luoma SN (1991) Time-courses in the retention of food material in the bivalves Potamocorbula amurensis and Macoma balthica: significance to the absorption of carbon and chromium. Mar Ecol Prog Ser 78:303-314

Fischer H (1988) Mytilus edulis as a quantitative indicator of dissolved cadmium. Final study and synthesis. Mar Ecol Prog Ser 48:163-174

Fischer H (1989) Cadmium in seawater recorded by mussels regional decline established. Mar Ecol Prog Ser 55: $159-169$

Flegal AR, Smith GJ, Gill GA, Sanudo-Wilhelmy S, Anderson LCD (1991) Dissolved trace element cycles in the San Francisco Bay estuary. Mar Chem 36:329-363

Goldberg ED, Koide M, Hodge V, Flegal AR, Martin J (1983) US Mussel Watch: 1977-1978 results on trace metals and radionuclides. Estuar Coast Shelf Sci 16:69-93

Gunther AJ, Davis JA, Phillips DJH (1987) An assessment of the loading of toxic contaminants to the San Francisco Bay-Delta. San Francisco Bay-Delta Aquatic Habitat Institute, Richmond, CA

Harris JE, Fabris GJ, Statham PJ, Tawfik F (1979) Biogeochemistry of selected heavy metals in Western Port, Victoria, and use of invertebrates as indicators with emphasis on Mytilus edulis planulatus. Aust $\mathrm{J}$ mar Freshwat Res 30: $159-178$

Jassby AD, Cloern JE, Powell TM (1993) Organic carbon sources and sinks in San Francisco Bay: variability induced by river flow. Mar Ecol Prog Ser 95:39-54

Johns C, Luoma SN (1990) Arsenic in benthic bivalves of San Francisco Bay and the Sacramento/San Joaquin River Delta. Sci total Environ 97/98:673-684

Krumgalz BS, Fainshtein G, Sahler M, Gorfunkel L (1989) 'Field error' related to marine sediment contamination Mar Pollut Bull 20:64-69

LaTouche YD, Mix MC (1982) The effects of depuration, size, and sex on trace metal levels in bay mussels. Mar Pollut Bull 13:27-29

Lobel PB (1987) Intersite, intrasite and inherent variability of the whole soft tissue zinc concentrations of individual mussels Mytilus edulis: importance of the kidney. Marine environ Res 21:59-71

Lobel PB, Bajdik CD, Belkhode SP, Jackson SE, Longerich HP (1991a) Improved protocol for collecting mussel watch specimens taking into account sex, size, condition, shell shape, and chronological age. Arch environ Contam Toxicol 21:409-414 
Lobel PB, Belkhode SP, Jackson SE, Longerich HP (1989) A universal method for quantifying and comparing the residual variability of element concentrations in biological tissues using 25 elements in the mussel Mytilus edulis as a model. Mar Biol 102:513-518

Lobel PB, Belkhode SP, Jackson SE, Longerich HP (1991b) Sediment in the intestinal tract: a potentially serious source of error in aquatic biological monitoring programs. Mar environ Res 31:163-174

Luoma SN (1983) Bioavailability of trace metals to aquatic organisms - a review. Sci Total Environ 28:1-22

Luoma SN, Cain DJ, Johansson C (1985) Temporal fluctuations of silver, copper, and zinc in the bivalve Macoma balthica at five stations in South San Francisco Bay. Hydrobiologia 129:109-120

Luoma SN, Dagovitz R, Axtmann E (1990) Temporally intensive study of trace metals in sediments and bivalves from a large river-estuarine system: Suisun Bay/Delta in San Francisco Bay. Sci total Environ 97/98:685-712

Luoma SN, Phillips DJH (1988) Distribution, variability, and impacts of trace elements in San Francisco Bay. Mar Pollut Bull 19:413-425

Martincic D. Nurnberg HW, Stoeppler M, Branica M (1984) Bioaccumulation of heavy metals by bivalves from Lim Fjord (North Adriatic Sea). Mar Biol 81:177-188

Metcalfe-Smith JL (1994) Influence of species and sex on metal residues in freshwater mussels (Family Unionidae) from the St. Lawrence River, with implications for biomonitoring programs. Environ Toxicol Chem 13: 1433-1443

Nichols FH, Thompson JK, Schemel LE (1990) Remarkable invasion of San Francisco Bay (California, USA) by the Asian clam Potamocorbula amurensis. II. Displacement of a former community. Mar Ecol Prog Ser 66:95-101

Phillips DJH (1976) The common mussel Mytilus edulis as an indicator of pollution by zinc, cadmium, lead and copper. II. Relationship of metals in the mussel to those discharged by industry. Mar Biol 38:71-80

Phillips DJH (1977) The use of biological indicator organisms to monitor trace metal pollution in marine and estuarine environments - a review. Environ Pollut 13:281-317

Phillips DJH (1985) Organochlorines and trace metals in green-lipped mussels Perna viridis from Hong Kong waters: a test of indicator ability. Mar Ecol Prog Ser 21: $251-258$

This article was subrnitted to the editor
Phillips DJH, Rainbow PS (1989) Strategles of trace metal sequestration in aquatic organisms. Mar environ Res 28 $207-210$

Rainbow PS (1993) The significance of trace metal concentrations in marine invertebrates. In: Dallinger $R$, Rainbow PS (eds) Ecotoxicology of metals in invertebrates. Lewis Publishers, Boca Raton, p 3-23

Rambow PS, Phillips DJH, Depledge MH (1990) The significance of trace metal concentrations in marine invertebrates: a need for laboratory investigation of accumulation strategies. Mar Pollut Bull 21:321-324

Rainbow PS, White SL (1989) Comparative strategies of heavy metal accumulation by crustaceans: zinc, copper and cadmium in a decapod, an amphipod and a barnacle. Hydrobiologia 174:245-262

Simkiss K, Taylor M (1981) Cellular mechanisms of metal ion detoxification and some new indices of pollution. Aquat Toxicol 1:279-290

Simkiss K, Taylor M, Mason AZ (1982) Metal detoxification and bioaccumulation in molluscs. Mar Biol Lett 3:187-201

Smith DR, Slephenson MD, Flegal AR (1986) Trace metals in mussels transplanted to San Francisco Bay. Environ Toxicol Chem 5:129-138

Smith GJ, Flegal AR (1993) Silver in San Francisco Bay estuarine waters. Estuaries 16:547-558

Southgate T, Slinn DJ, Eastham JF (1983) Mine-derived metal pollution in the Isle of Man. Mar Pollut Bull 14:137-140

Strong CR, Luoma SN (1981) Variations in the correlation of body size with concentrations of $\mathrm{Cu}$ and $\mathrm{Ag}$ in the bivalve Macoma balthica. Can J Fish Aquat Sci 38:1059-1064

Talbot V. Chegwidden A (1982) Cadmium and other heavy metal concentrations in selected biota from Cockburn Sound, Western Australia. Aust J mar Freshwat Res 33: $779-788$

Thompson JK, Nichols FH (1995) Conrol of a phytoplankton bloom in San Francisco, CA by the filter feeding bivalve Potamocorbula amurensis. In: Hollibaugh JT (ed) San Francisco Bay: the managed estuary. Pacific Division, AAAS, San Francisco (in press)

Thomson EA, Luoma SN, Johansson CE, Cain DJ (1984) Comparison of sediments and organisms in identifying sources of biologically available trace metal contamination. Wat Res 18:755-765

Zar JH (1984) Biostatistical analysis. Prentice-Hall, Inc, Englewood Cliffs, NJ

Manuscript first received: October 31, 1994

Revised version accepted: March 8, 1995 